\title{
The Mythological Power of Hospitality Leaders? A hermeneutical investigation of their reliance on storytelling.
}

\section{Abstract}

Purpose - To explore how senior leaders in the hospitality industry use storytelling to disseminate their vision to employees. To illustrate how hermeneutics can be used as a method for the interpretation of qualitative data in hospitality management research.

Design/methodology/approach - A purposeful criterion based sample design was constructed and after a period of sensitisation to their organisations, twenty phenomenological interviews with high level international hospitality industry leaders were conducted. These interviews are analysed using a hermeneutical framework.

Findings - Storytelling is being used as a strategic method of communication and is fundamental to leadership in the contemporary commercial hospitality industry; stories are used to strengthen and revitalise current norms and values. Stories penetrate organisations and tap into the emotions of employees in order to inspire action and understanding.

Research limitations/implications - Hermeneutics is applied clearly and concisely and the paper demonstrates how hermeneutics could easily be adapted for other projects. Clear direction for further research is suggested, exploring the efficaciousness of stories from the listeners' rather than narrator's perspective

Practical Implications - This paper does not teach managers how to tell stories, or even make them better storytellers; however, it highlights how storytelling is used by leaders at the apex of the commercial hospitality industry to develop and enhance organisational culture.

Originality/value - Within hospitality management research, storytelling has mostly been ignored both as a management tool and as a form of data collection; similarly hermeneutics as a means of data analysis does not feature in the hospitality management literature. 


\section{Introduction}

Within hospitality management literature storytelling has mostly been ignored, both as a management tool and as a form of data collection; this paper begins to address that oversight by exploring how senior leaders in the hospitality industry use storytelling to disseminate their vision to employees. Through qualitative enquiry, phenomenological interviewing and then hermeneutically analysing the interview transcripts this research, both seriously and sympathetically, engages with the stories that the leaders tell about themselves. This research engages with hospitality industry leaders, getting them to tell stories about themselves, and also those that they tell to others. What is clearly shown in the results is just how central personal storytelling is to the creation and dissemination of their vision within their organisations.

Storytelling, no doubt, is as old as mankind; however, only since the post-Mediaeval age of The Enlightenment, and the rise of Rationalism in the Western world at least, has the written word been constrained and subjugated by the need for clear ideas which correspond to the physically possible. For instance, dragons were often reported as being hunted in the Dark Ages and the King James Bible, first published in 1611, refers several times to the unicorn. Imagination and a refusal to take things at face value play a large part in scientific understanding and discovery. The ability to take an imaginative leap, beyond accepted scientific dogma, the entrenched views of academic colleagues, disciplinary boundaries or even apparent common sense, has been central to many of the scientific and technological advances of the last few hundred years. Indeed, this is true even in disciplines which seem to be rooted in objective fact and cold hard logic, as the physicist Max Planck said, "New ideas are not generated by deduction, but by an artistically creative imagination ... Science, like the humanities, like literature, is an affair of the imagination" (as cited in McFague 1982: 75).

Brown, Denning, Groh, and Prusak (2004, p. 1) observe:

"to some people - people in business, people in management, people running public sector organizations - storytelling might seem like an odd subject to be talking about at all. The thought that narrative and storytelling might be important ideas in organizational thinking in the coming century might seem even odder."

In sharp contrast to such misgivings, anthropologists like Bochner (2001) and Goodall (2005) describe man as homo narrans, the storytelling creature; arguing that humans are naturally, profoundly, and often captivatingly oriented toward storytelling. This paper develops the concept of homo narrans, by exploring how leaders in the hospitality industry use storytelling. It does not address the full panoply of storytelling but rather focuses on the stories, or personal narratives, leaders offer about themselves or the company to their employees. 


\section{Storytelling in Anthropology}

The introduction highlighted a dichotomy that seems to exist with hospitality management: it is known that homo narrans tells stories, but these stories have been ignored as a data source within the subject. Problematically, this appears particularly incongruous with the nature of the hospitality industry where so much is dependent on reputation and myth. The meaning of a story is not encapsulated by individual words, rather it subsists within the total scenario that is envisioned by the narrator; this intending meaning may or may not be fully grasped by the listener. However, in business and management studies, and the wider social sciences, the importance of storytelling has been recognised for some time. Cupitt (1991, p. ix) offers a definition of what stories are,

"Stories are interpretative resources, models and scenarios through which we make sense of what is happening to us and frame our action. Unlike the forms and concepts of philosophy, stories are stretched out in time... They shape the process of life. It is through stories that our social selves, which are our real selves, are actually produced"

Within the anthropology of storytelling, Chand (2006), Havelock (1988), Hummel (1991), Koenig (2008), and Orr (2009) all credit stories as being a useful form of communication. Dyer and Wilkins (1991) go as far as suggesting that research itself is rooted in the structures of narrative commentary, thus the concept is self-perpetuating, allowing research to scratch progressively beneath the surface of the subject area. Although Dyer and Wilkins (1991) cite this as an evolution of methodological tact, Clegg (1993, p. 44) observes,

"What was recognised was that disciplines in the social sciences ranging from sociology to ethnography and to organisation studies had long been founded on the ability to tell a good story"

Armstrong (2006) links the modern idea of stories to the tradition of telling myths. Through the process of interacting with the images presented by a story, the listener comes to terms with the meaning created by the storyteller. Brown and Schneiders (1997, p. 1288) offer insight into the power of myths,

"Mythological thinking is the only way in which the mind can approach certain problems that lie beyond certain experience. These problems involve some of the most important questions one can ask."

Such a proposition points to storytelling being the only effective method of approaching certain situations, as some concepts may be difficult to relate to or adequately contextualise. Furthermore, the incongruity between the current practice in hospitality and 
the nature of storytelling is compounded by the apparent lineage between the intangible elements of hospitality and stories being a useful way of packaging challenging and abstract concepts. The context within which a story is told will give the listener perspective which can be used to rationalise the conclusions reached from listening to a story. Armstrong (2006) continues by highlighting the usefulness of stories through their capacity to help the listener reach their own conclusions, rather than simply providing the listener with answers. Therefore, stories can illustrate ideas that extend beyond everyday reality, help the listener seek meaning, and then relate their own experiences to this meaning. Armstrong (2006) also identifies imagination as being an integral aspect of storytelling both for narrator and listener, just as McFague (1982) notes. Ancient myths are described as a means through which routine and ritual were understood, an explanation that hints towards stories' modern application to business practice. On a more fundamental level Armstrong (2006, p. 6) describes stories as being designed, "to help us cope with the problematic human predicament", relating back to the idea of stories guiding one to a deeper understanding of a problem or situation.

Given the recognition of storytelling in the wider business literature it is surprising that that it has been largely ignored in hospitality research. Neglect of the topic may be due to its apparent lack of factual reliability. However, as this paper demonstrates this problem is far from insurmountable and indeed the topic holds a particular relevance to the hospitality industry.Armstrong (2006) and Ifversen (2003) highlight the power of storytelling in its effect rather than its reliability. Therefore, the reliability of stories as data sources, according to Armstrong (2006) and Ifversen (2003), is found in the insight they provide to their audience as opposed to the truthfulness of the story itself. This point underpins Armstrong's (2006, p. 11) assertion that,

"As our circumstances change, we need to tell our stories differently in order to bring out their timeless truth."

In this sense the concepts of fact and truth become quite different things; Clandinin and Connelly (2000) find that fact and fiction can be blurred by stories but conclude that they still reveal truths and insights. Wachtman and Johnson (2009) and Grisham (2006) note that the recurring characteristic of a story is to capture the listener's imagination in an effort to inspire them to reach a conclusion. The idea of inspiration and guiding the listener to a desired conclusion through storytelling is described by Simmons (2006) as a 'pull' strategy of influence: one that achieves the trust of the listener whilst helping them learn.

However important stories are to communication, often they are merely viewed as a form of entertainment, yet in reality they have other functions: they stimulate the imagination and offer reassurance (Bettelheim, 1976); they provide moral education (Maclntyre, 1981); they justify and explain (Kemper, 1984); and they inform, advise, and warn (Van Dijk, 1975). Broadly speaking, from an anthropological perspective the conceptual element of a story allows it to be interpreted across cultural, geographical, and even temporal boundaries. Stories employ metaphorical language, which allows people to more easily discuss and conceptualise complex ideas. 


\section{Organisational Storytelling}

In organizational studies, Allan, Fairtlough and Heinzen (2002) observe that stories are not a pleasant embellishment; rather, they are a vital resource for getting the right things done. Stories evolve gracefully over time, as different speakers and audiences use them, and as an organisations change; thus stories and an organisation's culture co-evolve. Kjaerbeck and Asmub (2005) consider the listener's (or employee's) construction of meaning a central activity in the negotiation of meaning. Rhodes and Brown (2005) in an extensive review of narratives/storytelling in organizational research, particularly in the area of organizational culture, note that the stories people tell about themselves or the company provide another form of institutional knowledge. Observing that most storytelling research is undertaken using a positivistic methodology, they propose that in future research there is the need to study organisations "seriously and sympathetically - as a means to understand rather than to control, to accept ambiguity rather than demand certainty, and to engage with lived experience rather than to abstract from it" (Rhodes \& Brown, 2005, p. 182).

In business, Daft (1999) makes the point that stories about the company, managers and employees are recounted to new and untrained employees to portray a company's principal values and are employed by leaders to keep values alive and provide shared understanding. Denning (2000), former director at the World Bank, claims to be the author of "the first book to teach storytelling as a powerful and formal discipline for organizational change and knowledge management". Denning (2000: xix), after expressing an initial scepticism about the use of storytelling in business, becomes convinced that effective storytelling can foster support for business goals; observing that a "story has an impact not so much through transferring large amounts of information, as through catalyzing understanding". Denning (2004b) explores the structure of personal stories and narratives, and explains how he a better storyteller. He suggests, in conclusion, that leaders should do the following in their stories: spark action (transformation), communicate who you are (trust, empathy), transmit values, foster collaboration, tame rumours, share knowledge, and lead people willingly into the future. As well as this, other research has identified a range of functions that storytelling facilitates in organisations: accounting (Lichtman, 2009); increasing sales (Grover, 2009; Wachtman \& Johnson, 2009); and strategic change (Adamson, Pine, Van Steenhoven, \& Kroupa, 2006; Boal \& Schultz, 2007; S. Denning, 2004a; Wycherley, 2005). The potential application of storytelling has become so diverse and integral to organisational behaviour that Hansen (2008) reports on consultancy firms that have emerged who base their entire product on improving storytelling capabilities among organisational leaders.

In an age where machines and structured protocol stand in place of traditional, small firm methods of organisational operation and communication, Brown et al. (2005) discuss the ability of storytelling to permeate an organisation with unparalleled speed and depth of understanding. Brown et al. (2005) discover that the social fabric of an organisation is one of its most powerful resources. Although this network is intangible compared to company intranets or similar communication portals, utilising an organisation's social fabric through 
storytelling can convey a more complicated message with far greater penetration than other methods of communication. The effectiveness of storytelling in this sense lies in a story's ability to relay a message and impart clear understanding of it. Denning (2005) builds on this idea, noting that the bond created between the listener of a story and the protagonist can establish a close sense of community between leaders of large multinational corporations and their employees, thereby transcending national, cultural and hierarchical barriers. Mitroff and Kilmann (1976) based a study around the short stories managers within organisations use in order to convey their idea of an ideal organisation, the apparent penetration of these stories illustrates the potency of such narratives.

The soft characteristics of storytelling give a different perspective to contemporary organisational leaders, Kets de Vries (2001, p. 260) states, leaders "are likewise good at different forms of symbol manipulation", as he goes on to compare leadership to theatre, where leaders are actors who set the scene and use imagery. Indeed, comparisons between leaders using storytelling and theatre are unavoidable, as both aim to entertain, inform and influence. A distinguishing feature, however, is story's ability to induce action amongst others without the individuals feeling as though they are being dictated to, this theme transcends organisational theory. Through inspirational rhetoric, actors, guide and nurture a more sensitive approach to leadership than one might initially expect in the modern era. The use of storytelling to inspire action in others is cited by Denning (2006), Harris and Barnes (2006), Shelton (2008) and Wycherley (2005) as a key function of storytelling within organisational culture. And the continuation of a storytelling culture among leaders seems likely since Harris and Barnes (2006) find that the use of storytelling lays a pathway of understanding and knowledge for future leaders within an organisation.

There are relatively few studies of storytelling in hospitality and it is a line of research that requires expansion; the limited examples are identified here. Boje (1995) in exploring Disney analysed the stories that organization members told about themselves and found them to be as artfully constructed and as carefully edited as the Disney characters. Through a postmodern analysis of these multiple discourses the research revealed that they excluded stories of the darker side of Disney. In researching a restaurant chain Jameson (2001) demonstrated that intra-organisational stories had a strong unifying power, often uniting the individual unit's management teams against the corporate headquarters. Paraskevas (2006) presented a narrative analysis, lacking a clear analytical framework, consisting of a case study of a hotel chain facing a major food poisoning outbreak, where data seems to have been gathered from 17 in-depth interviews of persons involved in the crisis response. These three studies all lack a transparent and replicable methodology for analysing the stories that are gathered in the data collection, highlighting the need for a viable, robust and justifiable methodology. 


\section{Methodology}

\section{Hermeneutics}

According to Brown and Schneiders (1997)hermeneutics, originally concerned with interpreting sacred texts, has developed over time into a scientific methodology (Bohman, 1999). The researcher enters into a dialogue using the understanding gathered from the text and drawing on their pre-understanding to interpret the phenomena under investigation in the hope of revealing something that is hidden. Alvesson and Sköldberg (2004) called this stage 'alethic hermeneutics,' from the Greek aletheia (uncoveredness). This is developed from Heidegger (1927/1982) who stated that hermeneutics allowed the revelation of something hidden. The method is dependent on the inferences made by the researcher and the meanings the researcher then attributes to elements of the texts (McAuley, 2004). Applied to leadership it is essentially the interpretation of meanings from experiences related as meaningful by the interviewees, or at least as what they might want the researcher to think of as meaningful to them.

Increasingly, hermeneutics is being adopted as a data analysis technique across business research. Hermeneutics has been employed by a wealth of disciplines and is seen regularly in the core business literature as an accepted and effective means of data analysis. Table 1 illustrates the different ways in which hermeneutics has been applied across the business literature.

[Take in Table 1: Applications of Hermeneutics in Business and Management Research]

Table 1 shows four core business subjects where hermeneutics is widely applicable to research. Within these disciplines, the subject areas that have used hermeneutics are diverse, ranging from accounting philosophy to effective methods of strategic change management.

\section{Research Design and Data Collection}

This research explores how senior leaders in the hospitality industry use storytelling to disseminate their vision to employees. The research design is framed with an interpretivist paradigm, partly to address the concerns of Rhodes and Brown (2005), also it is seeking to observe and also interpret the general trends and perceptions of a social phenomenon. Strauss and Corbin (1990) observe that interpretivist methods are useful for unravelling and understanding what lies behind any phenomenon about which little is known.

A purposeful criterion based sample design was selected. Creswell (2007, p. 125) notes that this type of sample allows the selection of interviewees that can "purposefully inform an understanding of the research problem and central phenomenon in the study". In total 20 
interviews took place with high level international hospitality industry leaders including Founders, Chairmen, Chief Executive Officers and General Managers: Table 2 gives details concerning the interviewees, location of interview and amount of raw data that was collected. Before the interviews, a period of sensitisation to each organisation was also undertaken and formal and informal meetings were conducted with members of the executive team in the various organisations. This enabled the interviewer to have a greater understanding of the organisational culture and obtain a more in-depth perspective of the leaders in question.

[Take in Table 2: Leaders interviewed for the research]

The interviews were phenomenological, ranging in duration from ninety minutes to two hours; these interviews were recorded and then transcribed. The phenomenological interviews in this research consisted of, the interviewer, who was already familiar with the interviewee and their organisation, encouraging the leaders to tell Type One stories about themselves or their own organisations and how they disseminate their vision.

- Type One - Stories that are used, in this research, as a means of getting people to relate their experiences in their own words.

- Type Two - Stories that are told with a view to engaging an audience, or teaching the audience insights or lessons. In this research, these stories were gleamed from the Type One stories told by the interviewees during the phenomenological interviews.

Both Type One and Type Two stories could be a useful means of data collection as they provide the potential for insights into corporate culture, and in particular the message the leader wishes to disseminate. This research into storytelling is not to enable the researcher to tell better stories, but to enable the reader to understand how stories are used to relate a vision, to benefit the storyteller, and often to the advancement of the company or organisation.

Kvale (1983) argues that the types of data generated by phenomenological interviews are particularly well suited to hermeneutic analysis. A similar method was used by Thompson (1997) when illustrating a hermeneutically grounded interpretive framework for deriving marketing-relevant insights from the analysis of customers' stories. As with Thompson (1997), these interviews typically employ very few pre-planned questions.

\section{Data Analysis}

The method of data analysis used on the transcribed interviews is the hermeneutic circle of interpretation; this is a development of the method used by Morrison and O'Gorman (2008) to analyse the relevance of the Rule of St Benedict for contemporary hospitality 
management. Various authors, including Alvesson and Sköldberg (2004), Denzin (1989), Hayllar and Griffin (2005) and O'Gorman (2007) suggest and adopt four epistemological practices; meanwhile Van Manen (1990) proposes two methodological principles, for hermeneutical interpretation. O'Gorman (2008) adapted and developed both the epistemological practices and the methodological principles in hermeneutical research and presented them in a table; that table has been modified for this research (Table 3 ). The first column gives the name of the epistemological practices or methodological principles whereas the second column gives a generic description of how these could be applied to any research project. The third column details how these practices and principles are applied to this research and what the particular results are.

[Take in Table 3: Applied Hermeneutical Interpretation]

When the methodological principles and practices are combined they form, as described by Alvesson and Sköldberg (2004), the hermeneutic circle of interpretation, as is shown in Figure 1.

[Take in Figure 1: The Hermeneutic Circle of Interpretation]

This hermeneutic circle of interpretation is now used in this paper to reflect upon, discuss and analyse the transcribed interviews. This is done by making three consciously distinct revolutions of the hermeneutical circle; this process and a summary of the results obtained are shown in Table 4. In Table 4 the first column shows the level of analysis, the second column describes how that analysis took place, and finally the third column shows a summary of the results obtained from each stage of analysis.

[Take in Table 4: Review of the hermeneutical process]

The process began with an initial thematic analysis to explore the common devices used by the leaders; this identified that the leaders all used Type 2 stories. Then a first reflective analysis identified how the leaders used storytelling and finally a second reflective analysis allowed for the collation of examples of storytelling. These three revolutions of the circle also form the structure for the discussion and findings section, thus helping to bring into focus a sometimes-unclear picture. 


\section{Analysis and Discussion}

\section{Thematic Analysis}

During the initial thematic analysis of the transcribed interviews, storytelling constantly emerged as a theme, with the interviewees often providing examples of their own storytelling. Personal narratives as Type Two stories were told to their management team and to direct and influence employees, through personal anecdotes that are used to educate, a typical example is now retold.

“During the Royal Highland show held just West of Edinburgh, late in the service
period, lunch time, a middle aged man and a much younger woman came in and
asked for a bottle of Dom Perignon. But we didn't have any Dom Perignon, we
weren't actually that good. The General Manager got a bottle of Veuve Clicquot and
it wasn't chilled so he stuck it in the freezer and he asked me to go out and offer
them another drink which I did. I wasn't trained at this point I just had to do it.

I was not that familiar with beverages and certainly not with Champagne as I shortly proved. The General Manager instructed me on how to open the bottle of Champagne the lead foil, the wire, he recommended I use both thumbs while holding the bottle by the neck to ease the cork out, and said what is important is it comes out with an nice pop. And, having taken the Champagne out of the freezer where it had been in for all to short a time. He said and just to make sure it gives a good pop, hold the bottle by the neck in the left hand, and like a new born baby give it a couple of whacks on the bottom and he sent me forth into the dining room to serve this Champagne, well, following his procedure I took off the foil and the wire and started easing the cork out, and it came out with an explosion, followed by a spume of Champagne which substantially wetted the male individual, and the cork bounded off the high ceiling and there was nobody else to blame thank god, they might have been killed, and I said blushing to the roots of my hair, 'would you care to taste the Champagne, sir'. He picked up his napkin mopped himself off and said I already have.

From that I learned, do not send lambs to the slaughter. Have managers who are competent, have training systems that are effective. So many basics."

This story is taken from one of the very early interviews, and the same interviewee commented that he felt stories to be immensely powerful when communicating his message to the staff. Therefore by thematically analysing the Type One stories that the leaders told to the interviewer, it became clear that the hospitality industry leaders used Type Two stories as a strategic management device, often without even realising it. For example Ken McCulloch, a Scottish hotelier in delivering a true-story to a hospitality audience as part of an annual lecture series, showed a leader using a story that was both a type one and a type two story.

"The hospitality industry can be very strange, and we should tell the people who are about to come into our industry nothing can prepare you for some of the things that can happen. 
I will tell you a story that happened to me, probably ten or twelve years ago. It is a tragic story but a true story. It just proves that a lot of the time truth is stranger than fiction, totally. Picture this, there is a global conference in Glasgow, which Devonshire [One Devonshire, then one of McCulloch's signature properties] wasn't of a size that we could really play a part. But the organizers came to me and said, well, can we do something special. I said I would be delighted. This was an evening where we had a table for twelve at the back of the restaurant; we could curtain it so it wasn't as if they were in full display. The evening was going great, it was a Saturday evening, the top twelve people were doctors (they were the top table). They arrived, they were quite happy, it was a Saturday night so we were full. Everything seemed to be going fine. Halfway through dinner one of the doctors took ill and they said this man needs attention immediately, get the paramedics, we did that, the paramedics arrived in between ten and fifteen minutes, the gentleman was attended to and taken away. The whole thing probably took about fifteen minutes. The troops were absolutely amazing, but understandably upset. We dusted ourselves down and got on with our Saturday night. I wouldn't say we got back to the norm but it wasn't far off it. Word came back that evening that the gentleman was dead on arrival at the hospital, so it was just horrible, it was a horrible harrowing experience for everybody. But I was extremely proud of the way my management and my troops handled it. I thought they did it with great dignity and sincerity.

So, on the Monday morning I got a letter which read like this. [Ken reading directly from the letter.] 'Dear Mr McCulloch, my wife and I were dining in your establishment on Saturday evening, One Devonshire Gardens happens to be a very special place for us, particularly for special occasions. Saturday Night was our anniversary. Can you imagine our horror when we discovered that someone had actually died on Saturday evening in your restaurant? [Ken paused for effect in true storytelling mode to deliver the tag line] This is not what we have come to expect from an establishment such as One Devonshire Gardens. It ruined our entire evening'. Absolutely true, [by this point the assembled audience laughed incredulously.] I thought to myself, well it didn't do a great deal for the doctor either."

\section{First Reflective Analysis}

The previous example illustrates that when telling Type Two stories the leaders generally use anecdotes drawn from business life; as one leader said "the most powerful tools of persuasion are analogies between business experiences and what happens in real life". This is developed by one leader who uses the analogy of prehistoric times drawing analogies to the murky underworld of Platonic forms:

"if we were all cave people again, we could learn so much more from just thinking about what would be a natural reaction in a certain circumstance if you didn't have any business issues surrounding it, it was all just personal. It is likely that humans 
will react in a very similar way when faced with issues of a business nature on that front."

Another leader observed:

"The power of organizational storytelling is tremendous. Stories make information easier to remember and more believable. They are excellent for communicating values, ideas and norms. Our people can often be eased into the socialization of the organization and learn the ropes quicker through story and proto-story. I tend to relate stories of different kinds, with executives and managers, organizational stories, describing real events connected to the organization's culture and philosophy. For staff, it is better to utilize stories which situate them in the organization, and from which they can follow the guidance the story offers."

These three examples, along with many others from the interviews, show how these leaders, when in the public arena, behave more like actors. They stage-manage their storytelling, often with costly and thoughtfully designed sets behind them and act in particular ways at specific points to direct their businesses.

Type Two stories are used to motivate staff and share values, often by engaging in homespun folkloric discussion deliberately designed to inspire. As both Kets de Vries (2001) and Rhodes and Brown (2005) have indicated, the leaders try to ensure that the stories told contain something for everyone. They acknowledge that they are often talking to a highly sophisticated, well travelled and sometimes paying audience when they are working as consultants or speakers. They all believe in the development of their staff and Type Two stories are seen as an essential tool of staff development. One leader, who established his organization's own internal university, argued that focusing on developing the experience and enhancing the enjoyment of his staff will have a positive benefit for the customer. Another leader tells this story focusing on medium term career development in the hospitality industry:

"My primary advice about going into the hotel business is, do not go into the hotel business, it is a terrible business to be in. There are many reasons why it is a terrible, terrible business to be in. There are three reasons why it is a terrible business to be in. The hours are terrible, they are unsociable, you have to work Friday's, Saturday's, Easter Sunday, Christmas Day, all those awful times. So when all your friends are out partying on Friday and Saturday night forget about it, you are in the hotel. The hours are very long, there is no such things as an eight hour day. You have a day that is at least ten hours and maybe twelve hours and sometimes double shifts, that is the reality of our industry. Of course the pay is awful, absolutely terrible, until you get a little older. There is, of course, a positive and a negative to those things. When you are working those unsociable hours, you have other days off so there are no queues for the movies; you can always get a ticket to go to a show, to go out at night, you can always get restaurant reservations because nobody else is doing that. The long hours, yes they are there, but what a hoot! What a great time you are having when you are doing those long hours. You are meeting people, famous people, Heads of State, Princes, Princesses and Presidents. And then of course the pay, well you are working so hard anyway, you can't, you don't need the pay right? Nowhere to spend it!" 
As Daft (1999) and Denning (2004) both stated, communication within storytelling is critical and the leaders interviewed felt that they are judged by their employees on their ability to communicate with them. The message that they are communicating must be as competent as the delivery: "Your ability to lead is measured not only by what you do, and accomplish but by your competence and ability to communicate who you are and what you stand for as an organization". Storytelling is seen as a primary skill of all world-class leaders and a means of sustaining organisational culture. Type Two stories are used to engage employees in aspects of the leaders' vision and direction for the company. On the whole all the leaders placed a great deal of emphasis on auto-identification with the story; the employees had to believe that they were relating some part of their own past, thus sharing personal moments of their history. For example:

"I think you have to be a great storyteller. There is an interesting book by Henri René Albert Guy de Maupassant he is a French writer and he wrote a book called 'Belle Ami' and it is a story about a young man who really doesn't have anything and tries to make it in society and then he learns that the only way he can succeed and further himself is to tell good stories, I thought that is a great tag line. You need to have good stories because people listen to you. They also have something to compare, everyone has a story, and everybody if you really listen to it especially in the hotel I enjoy working with people who have a PhD, and then others who just came here from a refugee camp and are looking for a job. I am fascinated by listening to these people and then also sharing some of my stories. I think it is encouraging for them, when you tell them, you can give good advice which somehow has a relation to real life and then the other thing is - you have to listen, you have to listen and sometimes people just want to receive. There is an exchange of energy which eventually is some sort of bonding, which will you know creates some sort of loyalty and these people tend to work many years and do a lot of work for you, with a very positive attitude. When they can tell a story, guests also listen, there are many types of story they can tell, about themselves, the hotel its services etc."

As detailed in Table 3, from the first reflective analysis, apart from their sheer entertainment value, stories are effective as a leadership tool in general and also used for six other purposes: developing and sharing the storyteller's vision and mission for the company, helping to manage change, sharing personal and company values, developing trust, motivating, directing and influencing employees.

\section{Second Reflective Analysis}

During the first inductive analysis six principal uses of storytelling were identified. This second inductive analysis leads to the development of a taxonomy of storytelling. With a second reflective analysis of the interviews Table 5 has been constructed. Column one shows the six principal uses for Type Two stories identified by the first reflective analysis and column two shows practical examples of their usage. This table clearly illustrates how the 
hospitality leaders use Type Two storytelling to disseminate their vision throughout their organisation.

[Take in Table 5: How Hospitality Leaders Use Storytelling]

It also became clear that some of the leaders warn about the dangers inherent within storytelling, where a leader can become absorbed with obtaining the right effect. Dangers lie in biased, inequitable presentation, amended or embellished, mis-labelled, or subjectively framed story narrative. Stories can, at times, compromise accuracy and reality; they can contain contradictions, vagueness, myth, lacunae and much more. Where stories are unsupported by facts, they may well be more aligned with the core values and beliefs of the organization. For the researcher, danger lies in selective use of narrative by relying on inference, supposition and frames of reference which may present plausible stories to meet the need of the research or to underpin predetermined impressions and /or hypotheses, all of which represent significant hazards to story-based research. There are hidden dangers in the collective appeal of stories, the reality of which lies not in the facts, but in the meaning. Stories must be perceived as unbiased, reliable, and accurate, and thus able to enlist the emotions and the rich meaning to be found within them, for stories can be emotionally and symbolically inspiring narratives.

Through encouraging the leaders to tell Type One stories as a means of data collection this research shows that each of the hospitality industry leaders truly personifies the classification homo narrans. They are all storytelling leaders using Type Two stories with their employees and managers. The leaders themselves, through telling Type One stories, demonstrated the considerable extent to which they use Type Two stories in their business life.

Yet nothing found in the hospitality management literature suggests that storytelling is a central feature of hospitality management or training. The research shows that a story is perceived to be true because it is effective, not because it gives factual information, but because it gives new insight; if it does not do this then the story has failed. The storytellers readily accept that truth cannot be discarded but also acknowledge the limitations of facts in influencing people. Stories regularly better transmit meaning, bring clearer understanding from chaotic experience and enhance empathy between speaker and audience. Moreover, where the stories are not factually correct they must have a certain verisimilitude. The leaders are the storytellers, their employees, as co-narrators, are obliged to fully participate in the act of creating new realities through stories that they hear.

\section{Conclusions}

This paper has the dual intent of both exploring how senior leaders in the hospitality industry use their personal stories to disseminate their vision to their employees and to use 
the stories told in the interviews to example hermeneutics as a method for the interpretation of qualitative data in hospitality management. It is in the nature of fiction to expect and to accept things that are not part of reality. In the discussions of myths it was found that there are certain problems that only stories can truly relate to people and help them solve, thus their value lies in their ability to create an effect rather than convey fact.

The hospitality leaders interviewed show that, not only do stories transform into experience, but leaders' own experience also turns into stories which they then use in future stories. Storytelling is an enduring element of their daily lives and stories about themselves are used with practiced ease. Stories take on and become a significant part of company folklore; they are unorthodox, in the sense that they far removed from standard training and form part of a company's 'oral tradition' rather than part of a written corpus. Crucially it is this perceived unconventionality that gives stories a mythological power as they are not interpreted as mere corporate propaganda. The art of storytelling by these leaders is seen to help them deliver direction, information, insight and inspiration. It has been found that stories penetrate the fabric of an organization far more effectively than other forms of communication, making them invaluable to effective leadership. Furthermore, it is the ability to deliver a story that determines its true effectiveness thus good leadership depends on the ability to communicate experience as well as possessing it. This has proved that the apparent incongruence between leadership practice in the hospitality literature and the nature of hospitality in relation to storytelling is unfounded and indeed problematic; storytelling is commonplace for hospitality leaders. Stories do not always communicate information or evidence about events; nevertheless they develop, augment, and often imbue facts with particular meaning: in this paradox rests their strength and potential weakness. Storytelling improves productivity, teamwork and understanding, moreover it can produce discernible bottom line results, proving that the power of storytelling is indeed more than mythical, it is tangible and measurable.

Where the leaders use the their personal stories to engage their audience (employees and managers) researchers can also then use them as a source of data to explore corporate culture. Hospitality leaders see organizational stories as correlated to the strategic socioeconomical and socio-political environments in which they are aired. In this sense, a story's contribution is measured by its impact rather than accuracy. The qualitative, interpretivist practice, enabled the level of textual engagement needed for a fluid analysis rather than applying a fixed method of classification based on the quasi-quantification of qualitative data; meaning transcends word count. Table 3, which describes the epistemological practices and methodological principles of hermeneutics, and Table 4, which shows how the hermeneutical process is applied to this data set, could be easily adapted for, and applied to, other interpretivist and qualitative research projects. In Table 3 the first two columns of the tables are generic and only the third column is particular to this research. Whereas in Table 4 the first column (Level of analysis) is generic, the second column (Description of the analysis) and the third (Summary of the results obtained from the analysis) would need to be rewritten for each research project. When used together Tables 3 and 4 show clearly how hermeneutics is applied to this project and the tables could easily be adapted for other projects. 
With stories being reliant on their narrator and dependent on the subjective interpretation of the listener, there will undoubtedly be a dark side to stories. Stories have the potential to be equally effective at undermining organizational success or contaminating the reputation of a leader, if misinterpreted or employed maliciously. Future research could investigate the effect of stories from customers and staff and how these feed into the web of myth surrounding organisations. Such research would look at the use of storytelling in a bottomup context, rather than focusing on the top-down storytelling of leaders. Bearing in mind the increasingly immediate narrative democracy provided by online message boards, social networking sites and 'micro-blogging,' this realm of enquiry is particularly relevant. Furthermore, by looking at the interpretations of listeners, the biased opinions of leaders discussing the effectiveness of their own stories would be controlled.

So, in essence, this paper has clearly shown that one of the oldest data analysis techniques, hermeneutics, has been used to discover that one of the most ancient human skills, storytelling, is being continuously utilised to teach, inspire, influence and shape organisational culture in today's hospitality industry. Moreover the stories that leaders tell are a rich source of data and the application of hermeneutics as a data analysis technique enhances the quality of the findings.

\section{Acknowledgments}

The authors would like to extend their kind thanks to the editorial involvement of Tom Gaunt and Andrew MacLaren; their fresh perspectives and up to date knowledge offered invaluable help in developing the paper into its present form. 


\begin{tabular}{|c|c|c|}
\hline Discipline & Paper & Use of Hermeneutics \\
\hline Accounting & (Chabrak, 2005) & Offers a framework for exploring accounting policy from a more holistic perspective \\
\hline Accounting & (Chahine, 2006) & $\begin{array}{l}\text { Uses hermeneutics to explain the differences in earnings announcements, exploring good news announcements } \\
\text { and bad news announcements }\end{array}$ \\
\hline Accounting & (Coad \& Herbert, 2009) & Explores the move away from structuration theory in management accounting towards a more concrete construct \\
\hline Accounting & (Ferguson, 2007) & Critiques an existing 'textually orientated' approach to accounting through the use of hermeneutics \\
\hline Accounting & (Keller, Smith, \& Smith, 2007) & Uses hermeneutics to study the ethical standards within the accountancy industry \\
\hline Accounting & (Oakes \& Berry, 2009) & How coercive processes among organisations have created a colonising culture within accounting \\
\hline Economics & (Drechsler, 2000) & Critique the natural sciences in relation to social sciences \\
\hline Economics & (Frambach, 2006) & $\begin{array}{l}\text { Compares the social question and modern market economics through a combination of methodologies including } \\
\text { hermeneutics }\end{array}$ \\
\hline Economics & (Hjorth \& Johannisson, 2008) & An investigation into the central tendencies of Gartner's work using hermeneutics \\
\hline Economics & (Johansson, 2001) & Uses hermeneutics to analyse the value of consumption \\
\hline Economics & (Mathias \& Teresa, 2006) & Investigates the concept of capability and its apparent foundations in philosophy \\
\hline Economics & (Park \& Kayatekin, 2000) & Explores economic philosophy of standards of conversation through hermeneutics \\
\hline Economics & (Peach, 2002) & $\begin{array}{l}\text { Compares the theories of two prominent economists to illustrate their differences, although it suggests that } \\
\text { neither economist has a superior theory }\end{array}$ \\
\hline Economics & (PottsA, 2005) & $\begin{array}{l}\text { Explores capitalist theories to suggest more useful teaching techniques in economics. Uses hermeneutics to } \\
\text { explain why some Marxist views are conflicting. }\end{array}$ \\
\hline Economics & (Söderbaum, 2000) & Illustrates how hermeneutics, among other methodologies, is a vital tool in interpreting social science theories \\
\hline Management & (Brotheridge, 2005) & $\begin{array}{l}\text { Interviews managers to investigate ways in which interpretations of change alter as organisations go through } \\
\text { strategic change processes. }\end{array}$ \\
\hline Management & (Chiles, Bluedorn, \& Gupta, 2007) & $\begin{array}{l}\text { Maps the potential direction in which entrepreneurial theory would move if people were to adopt specific } \\
\text { perspectives. }\end{array}$ \\
\hline Management & (Crowley-Henry \& Weir, 2007) & $\begin{array}{l}\text { Uses analysis of in-depth interviews and contextual data to give insight into the career issues facing women } \\
\text { working in foreign countries. }\end{array}$ \\
\hline Management & (Hancock, 2006) & Examines the way in which organisational change influences spatio-temperal change within a wider context. \\
\hline Management & (Hartelius \& Browning, 2008) & Examines the influence of managers' rhetoric in communication within organisations. \\
\hline Management & (Heracleous, 2006) & Examines organisational discourse within human resource management within the UK. \\
\hline Management & (Heracleous \& Barrett, 2001) & $\begin{array}{l}\text { Analyses the discourse of communicative actions and the deep-rooted structures that relate to them within the } \\
\text { context of organisational change }\end{array}$ \\
\hline
\end{tabular}




\begin{tabular}{|c|c|c|}
\hline Management & (McWilliam \& Ward-Griffin, 2006) & Examine the experience of employees involved in organisational change within home care organisation in Canada. \\
\hline Management & (van Marrewijk, 2009) & $\begin{array}{l}\text { Discerns the interdependency of corporate architecture and organisational change and the need to endure wider } \\
\text { cultural value sets. Uses interviews, observations and participation. }\end{array}$ \\
\hline Management & (Waistell, 2006) & $\begin{array}{l}\text { Examines how metaphors mediate organisational change by analysing the speeches given by organisational } \\
\text { leaders }\end{array}$ \\
\hline Marketing & $\begin{array}{l}\text { (Ai-Ling, Dermody, \& Hanmer- } \\
\text { Lloyd, 2007) }\end{array}$ & $\begin{array}{l}\text { Researches 'mortal embodiment' within the context of cadaveric organ donation. Uses in depth interviews with } \\
\text { females. Describes data as, 'rich and thick' }\end{array}$ \\
\hline Marketing & (Areti \& Pierre, 2003) & $\begin{array}{l}\text { Investigates the interpretation of information in the contemporary market information tsunami. Looks at } \\
\text { Hermeneutics as a viable interpretive model. }\end{array}$ \\
\hline Marketing & (Chris, 2003) & $\begin{array}{l}\text { Divergence in advertising theory using hermeneutics to integrate the theories of divergence in advertising; } \\
\text { comparing results to establish the preconditions for advertising theory convergence }\end{array}$ \\
\hline Marketing & (Elena, Nancy, \& William, 2007) & $\begin{array}{l}\text { Uses hermeneutics to disseminate results from in-depth interviews investigating clothing consumption amongst } \\
\text { females in the post-socialist market. }\end{array}$ \\
\hline Marketing & $\begin{array}{l}\text { (Lowe, Carr, Thomas, \& Watkins- } \\
\text { Mathys, 2005) }\end{array}$ & $\begin{array}{l}\text { Offers three theoretical paradigms of consumer and market research, using hermeneutics to establish virtues of } \\
\text { these paradigms beyond their scientific cores. }\end{array}$ \\
\hline Marketing & (Palmer \& Ponsonby, 2002) & Uses hermeneutics to present the source of new marketing paradigms and explain their derivations. \\
\hline Marketing & (Yannopoulou \& Elliott, 2008) & $\begin{array}{l}\text { Analyses interpretation of print advertising in different communities by applying hermeneutics to the results of in- } \\
\text { depth interviews. }\end{array}$ \\
\hline
\end{tabular}




\begin{tabular}{|c|c|}
\hline \multicolumn{2}{|r|}{ Table 2: Leaders interviewed for the research } \\
\hline $\begin{array}{l}\text { Andrieu, Grace } \\
\text { Leo }\end{array}$ & President GLA Hotels. \\
\hline Bartels, Jurgen E & Former Chief Executive Officer, Le Méridien Hotel Group. \\
\hline $\begin{array}{l}\text { Bickson, } \\
\text { Raymond N. }\end{array}$ & $\begin{array}{l}\text { Managing Director, Taj Hotels Resorts and Palaces. Formerly, General Manager, } \\
\text { Mandarin Oriental Hotel, New York. }\end{array}$ \\
\hline $\begin{array}{l}\text { Campbell Gray, } \\
\text { Gordon }\end{array}$ & $\begin{array}{l}\text { Chairman, Campbell Gray Hotels. Founder and Managing Director, One Aldwych Hotel, } \\
\text { London, England }\end{array}$ \\
\hline Clavell, Victor & $\begin{array}{l}\text { Regional Vice President Europe, Ritz Carlton Hotel Company, General Manager, Hotel } \\
\text { Arts Barcelona. }\end{array}$ \\
\hline $\begin{array}{l}\text { Error! } \\
\text { Reference } \\
\text { source not } \\
\text { found., Sir Rocco }\end{array}$ & $\begin{array}{l}\text { Chairman and Chief Executive, The Rocco Forte Collection. Formerly Chairman and } \\
\text { Chief Executive of Forte Plc. }\end{array}$ \\
\hline Gelardi, Geoffrey & $\begin{array}{l}\text { Senior Vice President, Operations/Development Europe, Middle East and Asia. Managing } \\
\text { Director, The Lanesborough Hotel, London. }\end{array}$ \\
\hline Harris, Anthony & Former Chief Executive Officer, Hilton International Hotel Company. \\
\hline Kavanagh, J.P. & Operations Director, Starwood, The Westin Turnberry Resort, Scotland. \\
\hline Lambert, Liam & $\begin{array}{l}\text { Operations Director, Europe. Board Member, Mandarin Hotel Group. Chairman } \\
\text { Considerate Hoteliers. }\end{array}$ \\
\hline Leone, Paul & President. The Breakers Resort, West Palm Beach, Florida, USA. \\
\hline Mankarios, Atef & $\begin{array}{l}\text { Managing Partner, Mankarios Partnership. Has also served as President and Chief } \\
\text { Executive Officer, St Regis Hotels and Resorts. Past Chairman of the Board of Preferred } \\
\text { Hotels and Resorts Worldwide Inc, also formerly Chief Executive of Rosewood Hotels and } \\
\text { Resorts. }\end{array}$ \\
\hline $\begin{array}{l}\text { Mares, } \\
\text { Christophe }\end{array}$ & $\begin{array}{l}\text { General Manager, The Mandarin Oriental, Hyde Park, London. Former General Manager, } \\
\text { Mandarin Oriental Hotel Munich and Paris. }\end{array}$ \\
\hline McCulloch, Ken & $\begin{array}{l}\text { Founder, One Devonshire Gardens, and Malmaison Hotel Group, Chairman. McCulloch } \\
\text { Hotels Management. Scottish Hotelier of the Year } 2008 .\end{array}$ \\
\hline Pantin, David & $\begin{array}{l}\text { Chief Executive, Pantin Hotels. Former Managing Director, Rocco Forte Hotels and multi } \\
\text { unit management internationally as Vice President, Caribbean for Trusthouse Forte, Vice } \\
\text { President UK Operations for Hilton and Senior Vice President in the hotels division of } \\
\text { Hutchinson Whampoa. }\end{array}$ \\
\hline Selbie, Stuart & General Manager, Starwood, The Westin, Turnberry Resort. Scotland. \\
\hline Sharp, Isadore & $\begin{array}{l}\text { Founder, Chairman, Chief Executive and Member of Management Committee, Four } \\
\text { Seasons Hotels and Resorts. Connected to } 7 \text { Boards of Directors in } 7 \text { different } \\
\text { organizations across } 2 \text { different industries. }\end{array}$ \\
\hline $\begin{array}{l}\text { Tauscher, } \\
\text { Rudolph }\end{array}$ & $\begin{array}{l}\text { General Manager, Mandarin Oriental Hotel, Columbus Circle New York. Formerly did all } \\
\text { of the hotel openings for Donald Trump Corporation. }\end{array}$ \\
\hline Taylor, Kathleen & President and Chief Operating Officer, Four Seasons Hotels and Resorts. \\
\hline Young, John & $\begin{array}{l}\text { Former, Executive Vice President, Human Resources, Four Seasons Hotels and Resorts. } \\
\text { Consultant in the media, educational and service sectors. On the Board of Elizabeth } \\
\text { Arden Salons and Spas and Equinox Fitness, as well as an operating advisor to North } \\
\text { Castle Partners. }\end{array}$ \\
\hline
\end{tabular}




\begin{tabular}{|c|c|c|}
\hline \multicolumn{3}{|c|}{ Table 3: Applied Hermeneutical Interpretation } \\
\hline \multicolumn{3}{|c|}{ Epistemological Practices } \\
\hline Practice & Generic Description of Practice & Application to this research \\
\hline $\begin{array}{l}\text { Bracketing of } \\
\text { previous } \\
\text { experience and } \\
\text { turning toward } \\
\text { lived experience }\end{array}$ & $\begin{array}{l}\text { Presuppositions, biases, and any } \\
\text { knowledge of the phenomenon obtained } \\
\text { from personal and scholarly sources must } \\
\text { be set aside. After data collection the } \\
\text { researcher then enters into a dialogue with } \\
\text { the text using the understanding gathered } \\
\text { and drawing on their pre-understanding to } \\
\text { interpret the phenomena. }\end{array}$ & $\begin{array}{l}\text { Before the interviews, whenever possible } \\
\text { the researcher moved into the hotel and } \\
\text { conducted meetings with members of the } \\
\text { executive team allowing the interviewer to } \\
\text { focus a-priori on organizational culture and } \\
\text { allowing them to bracket their a-posterori } \\
\text { pre-conceptions. }\end{array}$ \\
\hline $\begin{array}{l}\text { Investigating the } \\
\text { Phenomenon }\end{array}$ & $\begin{array}{l}\text { It is important to clearly define the } \\
\text { phenomenon under investigation in order } \\
\text { for the data collection to remain focused. }\end{array}$ & $\begin{array}{l}\text { The interviews, despite being } \\
\text { phenomenological in style, always had a } \\
\text { sharp focus on exploring the means the } \\
\text { interviewees used to create a corporate } \\
\text { culture within their organisation. }\end{array}$ \\
\hline $\begin{array}{l}\text { Reflecting on } \\
\text { essential themes }\end{array}$ & $\begin{array}{l}\text { Moving from data collection to data } \\
\text { interpretation involves a process of } \\
\text { phenomenological reflection. The first step } \\
\text { in reflection is to conduct thematic } \\
\text { analysis, which helps give a degree of order } \\
\text { and control to the task. }\end{array}$ & $\begin{array}{l}\text { During the initial stages of the data } \\
\text { interpretation various themes emerged, } \\
\text { including: stages, signs, symbols, rights, } \\
\text { ceremonies and during these initial } \\
\text { reflections it became evident that Type } \\
\text { Two Stories were used by all the leaders }\end{array}$ \\
\hline $\begin{array}{l}\text { Writing and } \\
\text { rewriting }\end{array}$ & $\begin{array}{l}\text { During the analysis the procedure of asking } \\
\text { questions to the text, and listening to it, in } \\
\text { a dialogic form is central in the writing and } \\
\text { rewriting phase. Reflection and writing can } \\
\text { be false dichotomies as they tend to be } \\
\text { symbiotic tasks. }\end{array}$ & $\begin{array}{l}\text { The data was reviewed on several more } \\
\text { occasions to reveal all aspects of the use of } \\
\text { storytelling, this took place during the } \\
\text { writing and the rewriting stages. The very } \\
\text { act of writing aided considerably the } \\
\text { process of reflection. }\end{array}$ \\
\hline \multicolumn{3}{|c|}{ Methodological Principles } \\
\hline Principle & Generic Description of Principle & Application to this research \\
\hline $\begin{array}{l}\text { Maintain a strong } \\
\text { and oriented } \\
\text { relation }\end{array}$ & $\begin{array}{l}\text { Writing and interpretations must remain } \\
\text { oriented to the phenomenon under } \\
\text { investigation, thus superficialities and } \\
\text { falsities will be avoided }\end{array}$ & $\begin{array}{l}\text { In order to keep a tight focus on the } \\
\text { phenomenon, ideas emanating from the } \\
\text { data were constantly shared with academic } \\
\text { colleagues and other leaders in the } \\
\text { hospitality industry in order to gain co- } \\
\text { validation of thinking }\end{array}$ \\
\hline $\begin{array}{l}\text { Considering parts } \\
\text { and whole }\end{array}$ & $\begin{array}{l}\text { The overall interpretation is consistent with } \\
\text { the various parts of the analysis, step back } \\
\text { and look at the total, and how each of the } \\
\text { parts needs to contribute towards it. }\end{array}$ & $\begin{array}{l}\text { When formulating Table 4: How Leaders } \\
\text { Use Stories great care was taken to re-read } \\
\text { the original transcribed interviews to } \\
\text { ensure that the themes highlighted in the } \\
\text { table were a true and constant reflection of } \\
\text { the data. }\end{array}$ \\
\hline
\end{tabular}




\begin{tabular}{|c|c|c|}
\hline \multicolumn{3}{|c|}{ Table 4: Review of the hermeneutical process } \\
\hline $\begin{array}{l}\text { Level of } \\
\text { Analysis }\end{array}$ & Description of the analysis & $\begin{array}{c}\begin{array}{c}\text { Summary of the results obtained from the } \\
\text { analyses }\end{array}\end{array}$ \\
\hline Thematic & $\begin{array}{l}\text { To look for common themes } \\
\text { used by all the } 20 \text { leaders } \\
\text { interviewed to create corporate } \\
\text { culture within their organisation }\end{array}$ & $\begin{array}{l}\text { Variety of devices developing and sharing a core values } \\
\text { statement signs, symbols, rights, ceremonies. All leaders } \\
\text { seemed to place emphases on the importance and } \\
\text { centrality of telling Type Two stories. }\end{array}$ \\
\hline $1^{\text {st }}$ Reflective & $\begin{array}{l}\text { The initial inductive analysis } \\
\text { showed that storytelling is used } \\
\text { by all the leaders - the } \\
\text { interviews were re-read and } \\
\text { reflected upon for aspects of } \\
\text { storytelling used by the leaders }\end{array}$ & $\begin{array}{l}\text { From reflecting on the interviews it became clear that six } \\
\text { principle categories of storytelling were identified - } \\
\text { these were used by all or the vast majority of the } \\
\text { leaders. This was verified by working closely with other } \\
\text { academics in order to ensure that the emergent } \\
\text { presentation of results honestly reflected the data. } \\
\text { There was a considerable amount of writing and } \\
\text { rewriting at this stage, the vast majority of which did not } \\
\text { end up in the final draft. }\end{array}$ \\
\hline $2^{\text {nd }}$ Reflective & $\begin{array}{l}\text { A second reflective reading of } \\
\text { the interviews undertaken in } \\
\text { order to explore the interviews } \\
\text { for sub-categories showing } \\
\text { storytelling usage. }\end{array}$ & $\begin{array}{l}\text { Taxonomy of the uses of storytelling by leaders in the } \\
\text { hospitality industry was developed (Table 5). However, } \\
\text { at this stage, the warnings and concerns that the leaders } \\
\text { expressed about storytelling were also recorded to give } \\
\text { a holistic picture. The final table of results (Table 5) was } \\
\text { shown to some interviewees and other industry leaders } \\
\text { as a further means of verification and reflection. }\end{array}$ \\
\hline
\end{tabular}




\begin{tabular}{|c|c|}
\hline \multicolumn{2}{|c|}{ Table 5: How Hospitality Leaders Use Storytelling } \\
\hline Uses of Storytelling & Examples of Use \\
\hline Develop Vision and Mission & $\begin{array}{l}\text { Explain the mission of the company. } \\
\text { Articulate, define and sustain company culture. } \\
\text { Evolve with the organisation's culture. } \\
\text { Aid visualisation of the mission. } \\
\text { Develop vision for staff. }\end{array}$ \\
\hline Manage Change & $\begin{array}{l}\text { Articulate change in a non-frightening manner. } \\
\text { Identify challenges/opportunities. } \\
\text { Ignite and drive change. } \\
\text { Manage change through attitude. } \\
\text { Facilitate change by resolving conflict. }\end{array}$ \\
\hline Share Values & $\begin{array}{l}\text { Convey values. } \\
\text { Provide meaning and promote learning. } \\
\text { Create / anoint role models. } \\
\text { Help staff to consider the leaders values. } \\
\text { Help individuals to empathize. }\end{array}$ \\
\hline Develop Trust & $\begin{array}{l}\text { Build esprit de corps. } \\
\text { Establish rapport. } \\
\text { Disarm. } \\
\text { Improve morale. } \\
\text { Inspire self-development. }\end{array}$ \\
\hline Motivate Employees & $\begin{array}{l}\text { Enthuse and energize. } \\
\text { Captivate. } \\
\text { Motivate. } \\
\text { Show achievement. } \\
\text { Encourage creativity. } \\
\text { Engage participation. }\end{array}$ \\
\hline $\begin{array}{l}\text { Direct and Influence } \\
\text { Employees }\end{array}$ & $\begin{array}{l}\text { Deliver direction. } \\
\text { Help make sense of puzzling situations. } \\
\text { Mentor. } \\
\text { Easy to remember. } \\
\text { Educate and persuade. } \\
\text { Emphasize issues. } \\
\text { Turns dreams to goals. } \\
\text { Turns goals to results/script for conduct. }\end{array}$ \\
\hline
\end{tabular}




\section{Figure 1: The Hermeneutic Circle of Interpretation}

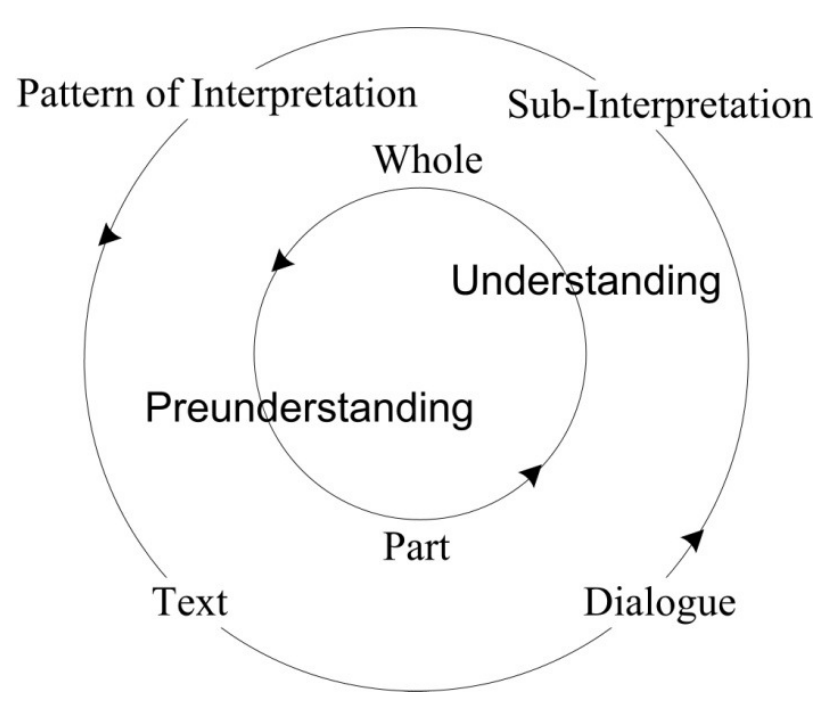

Source: Alvesson and Sköldberg (2004, p. 66)

\section{References}

Adamson, G., Pine, J., Van Steenhoven, T., \& Kroupa, J. (2006). How storytelling can drive strategic change. [Article]. Strategy \& Leadership, 34(1), 36-41.

Ai-Ling, L., Dermody, J., \& Hanmer-Lloyd, S. (2007). Exploring cadaveric organ donation: a 'mortal embodiment' perspective. [Article]. Journal of Marketing Management, 23(5/6), 559-585.

Allan, J., Fairtlough, G., \& Heinzen, B. (2002). The Power Of The Tale: Using Narratives for Organisational Success. Chichester: John Wiley \& Sons.

Alvesson, M., \& Sköldberg, K. (2004). Reflexive Methodology: New Vistas for Qualitative Research. London: Sage Publications.

Areti, K., \& Pierre, B. (2003). Making Meaning: Interpretive Diversity and Market Learning - A Model and Propositions. [Article]. Marketing Theory, 3(2), 187-208.

Armstrong, K. (2006). A short history of myth: Canongate US.

Bettelheim, B. (1976). The Uses of Enchantment: The Meaning and Importance of Fairytales. London: Thames \& Hudson.

Boal, K. B., \& Schultz, P. L. (2007). Storytelling, time, and evolution: The role of strategic leadership in complex adaptive systems. [Article]. Leadership Quarterly, 18(4), 411428.

Bochner, A. (2001). Narrative's Virtues. Qualitative Inquiry, 7, 131-157.

Bohman, J. (1999). Hermeneutics. In R. Audi (Ed.), The Cambridge Dictionary of Philosophy (pp. 89-91). Cambridge: Cambridge University Press. 
Boje, D. M. (1995). Stories of the Storytelling Organization: A Postmodern Analysis of Disney as 'Tamara-Land. Academy of Management Journal, 38(4), 997-1035.

Brotheridge, C. M. (2005). A test of the evolution and predictive capacity of managers' interpretations of change. [Article]. Journal of Change Management, 5(3), 281-294.

Brown, J., Denning, S., Groh, K., \& Prusak, L. (2005). Storytelling in organizations: Why storytelling is transforming 21st century organizations and management: Butterworth-Heinemann.

Brown, J. S., Denning, S., Groh, K., \& Prusak, L. (2004). Storytelling in Organizations: Why Storytelling Is Transforming 21st Century Organizations and Management. Oxford: Butterworth-Heinemann.

Brown, R. E., \& Schneiders, S. M. (1997). Hermeneutics. In R. E. Brown, J. A. Fitzmyer \& R. E. Murphy (Eds.), The New Jerome Biblical Commentary (pp. 1146-1165). London: Geoffrey Chapman.

Chabrak, N. (2005). The politics of transcendence: hermeneutic phenomenology and accounting policy. [Article]. Critical Perspectives on Accounting, 16(6), 701-716.

Chahine, S. (2006). Differential Interpretations, Private Information and Trading Volume Around French Firms' Good News vs. Bad News Preliminary Announcements. [Article]. European Accounting Review, 15(3), 403-429.

Chand, V. (2006). Linguistic Anthropology. Current Anthropology, 47(3), 407-407.

Chiles, T. H., Bluedorn, A. C., \& Gupta, V. K. (2007). Beyond Creative Destruction and Entrepreneurial Discovery: A Radical Austrian Approach to Entrepreneurship. [Article]. Organization Studies (01708406), 28(4), 467-493.

Chris, H. (2003). Divergent representational practices in advertising and consumer research: some thoughts on integration. [Article]. Qualitative Market Research: An International Journal, 6(3), 175-183.

Clandinin, D. J., \& Connelly, F. M. (2000). Narrative Enquiry: Experience and Story in Qualitative Research. San Francisco: Jossey-Bass.

Clegg, S. R. (1993). Narrative, power and social theory. In D. K. In Mumby (Ed.), Narrative and Social Control: Critical Perspectives (pp. 16-45). Newbury Park: Sage.

Coad, A. F., \& Herbert, I. P. (2009). Back to the future: New potential for structuration theory in management accounting research? [Article]. Management Accounting Research, 20(3), 177-192.

Cresswell, J. W. (2007). Qualitative Inquiry and Research Design: Choosing Among Five Approaches. Thousand Oaks: Sage.

Crowley-Henry, M., \& Weir, D. (2007). The international protean career: four women's narratives. [Article]. Journal of Organizational Change Management, 20(2), 245-258.

Cupitt, D. (1991). What is a story? : SCM Press.

Daft, R. L. (1999). Leadership Theory and Practice. Fort Worth: The Dryden Press.

Denning, S. (2000). The Springboard: How Storytelling Ignites Action in Knowledge-Era Organizations. Oxford: Butterworth-Heinemann.

Denning, S. (2004a). Squirrel Inc.: a fable of leadership through storytelling: Jossey-Bass.

Denning, S. (2004b). Telling Tales. Harvard Business Review, 82(5), 122-129.

Denning, S. (2005). The leader's guide to storytelling: mastering the art and discipline of business narrative: Jossey-Bass.

Denning, S. (2006). Effective storytelling: strategic business narrative techniques. [Article]. Strategy \& Leadership, 34(1), 42-48.

Denzin, N. K. (1989). Interpretive Interactionism. Newbury Park.: Sage.

Drechsler, W. (2000). On the possibility of quantitative-mathematical social science, chiefly economics. [Article]. Journal of Economic Studies, 27(4/5), 246. 
Dyer, W. G. J., \& Wilkins, A. L. (1991). Better stories, not better constructs, to generate better theory: a rejoinder to Eisenhardt. Academy of Management Review, 16, 613620.

Elena, K., Nancy, N.-H., \& William, T. (2007). Making sense of the market: An exploration of apparel consumption practices of the Russian consumer. [Article]. Journal of Fashion Marketing \& Management, 11(1), 106-121.

Ferguson, J. (2007). Analysing accounting discourse: avoiding the "fallacy of internalism.". [Article]. Accounting, Auditing \& Accountability Journal, 20(6), 912-934.

Frambach, H. (2006). The social question and fundamental principles of modern market economics - there is more - agreement than contradiction. [Article]. Journal of Economic Studies, 33(3), 224-236.

Goodall, H. L. (2005). Narrative Inheritance: A nuclear family with toxic secrets. Qualitative Inquiry, 11, 492-513.

Grisham, T. (2006). Metaphor, poetry, storytelling and cross-cultural leadership. [Article]. Management Decision, 44(4), 486-503.

Grover, R. (2009). Selling by Storytelling. [Article]. BusinessWeek(4132), 48-49.

Hancock, P. (2006). The spatial and temporal mediation of social change. [Article]. Journal of Organizational Change Management, 19(5), 619-639.

Hansen, K. (2008). Tell me a story. [Article]. In the Black, 78(5), $42-45$.

Harris, J., \& Barnes, B. K. (2006). Leadership storytelling. [Article]. Industrial \& Commercial Training, 38(6/7), 350-353.

Hartelius, E. J., \& Browning, L. D. (2008). The Application of Rhetorical Theory in Managerial: Research A Literature Review. [Article]. Management Communication Quarterly, 22(1), 13-39.

Havelock, E. (1988). The muse learns to write: Reflections on orality and literacy from antiquity to the present: Yale Univ Pr.

Hayllar, B., \& Griffin, T. (2005). The Precinct Experience: a phenomenological approach. Tourism Management, 26, 517-528.

Heidegger, M. (1927/1982). Grundprobleme der Phänomenologie. The Basic Problems of Phenomenology. Translation, introduction and lexicon by Albert Hofstadter. Bloomington: Indiana University Press.

Heracleous, L. (2006). A Tale of Three Discourses: The Dominant, the Strategic and the Marginalized. Journal of Management Studies, 43(5), 1059-1087.

Heracleous, L., \& Barrett, M. (2001). Organizational Change As Discourse: Communicative actions and deep structures in the context of information technology implementation. Academy of Management Journal, 44(4), 755-778.

Hjorth, D., \& Johannisson, B. (2008). Building new roads for entrepreneurship research to travel by: on the work of William B. Gartner. [Article]. Small Business Economics, 31(4), 341-350.

Hummel, R. P. (1991). Stories managers tell: why they are valid as science. Public Administration Review, 51, 31-41.

Ifversen, J. (2003). Text, Discourse, Concept: Approaches to Textual Analysis. Kontur, 7, 6069.

Jameson, D. A. (2001). Narrative Discourse and Management Action. Journal of Business Communication, 38(4), 476-511.

Johansson, P.-O. (2001). Is there a meaningful definition of the value of a statistical life? [Article]. Journal of Health Economics, 20(1), 131-139.

Keller, A. C., Smith, K. T., \& Smith, L. M. (2007). Do gender, educational level, religiosity, and work experience affect the ethical decision-making of U.S. accountants? [Article]. Critical Perspectives on Accounting, 18(3), 299-314. 
Kemper, S. (1984). The Development of Narrative Skills: Explanations and Entertainment In S. A. Kuczaj II (Ed.), Discourse Development: Progress in Cognitive Development Research. New York Springer-Verlag.

Kets De Vries, M. (2001). The Leadership Mystique. London: Prentice Hall.

Kjaerbeck, S., \& Asmuß, B. (2005). Negotiating Meaning in Narratives: An investigation of the interactional construction of the punchline and the post punchline sequences. Narrative Inquiry, 15, 1-24.

Koenig, K. (2008). Storytelling: An Encyclopedia of Mythology and Folklore. [Book Review]. Library Journal, 133(20), 166-170.

Kvale, S. (1983). The Qualitative Research Interview: A Phenomenological and Hermeneutical Mode of Understanding. Journal of Phenomenological Psychology, 14(4), 171-196.

Lichtman, S. H. (2009). The Power of Storytelling. [Article]. CPA Journal, 79(4), 6-8.

Lowe, S., Carr, A. N., Thomas, M., \& Watkins-Mathys, L. (2005). The fourth hermeneutic in marketing theory. [Article]. Marketing Theory, 5(2), 185-203.

Maclntyre, A. (1981). After Virtue. London: Duckworth.

Mathias, N., \& Teresa, H. R. (2006). A hermeneutic of Amartya Sen's concept of capability. [Article]. International Journal of Social Economics, 33(10), 710-722.

McAuley, J. (2004). Hermeneutic Understanding. In C. Cassell \& G. Symon (Eds.), Essential Guide to Qualitative Methods in Organizational Research (pp. 192-202). London: Sage Publications.

McFague, S. (1982). Metaphorical Theology: Models of God in Religious Language. London: SCM Press.

McWilliam, C. L., \& Ward-Griffin, C. (2006). Implementing organizational change in health and social services. [Article]. Journal of Organizational Change Management, 19(2), 119-135.

Mitroff, I. I., \& Kilmann, R. H. (1976). On organizational stories: an approach to the design and analysis of organizations through myths and stories. In R. H. Kilmann, L. R. Pondy \& D. P. Slevin (Eds.), The Management of Organizational Design (Vol. 1, pp. 189207). New York: North-Holland.

Morrison, A., \& O'Gorman, K. D. (2008). Hospitality Studies and Hospitality Management: A Symbiotic Relationship. International Journal of Hospitality Management, 27(2), 214227.

O'Gorman, K. D. (2007). Dimensions of Hospitality: Exploring Ancient and Classical Origins. In C. Lashley, A. J. Morrison \& P. Lynch (Eds.), Hospitality: A Social Lens. Advances in Tourism Research (pp. 17-32). Oxford: Elsevier.

O'Gorman, K. D. (2008). The Essence of Hospitality from the Texts of Classical Antiquity: The development of a hermeneutical helix to identify the philosophy of the phenomenon of hospitality. University of Strathclyde, Glasgow.

Oakes, H., \& Berry, A. (2009). Accounting colonization: Three case studies in further education. [Article]. Critical Perspectives on Accounting, 20(3), 343-378.

Orr, Y. (2009). Public Anthropology. Current Anthropology, 50(4), 413-413.

Palmer, A., \& Ponsonby, S. (2002). The Social Construction of New Marketing Paradigms: The Influence of Personal Perspective. [Article]. Journal of Marketing Management, 18(1/2), 173-192.

Paraskevas, A. (2006). Crisis Management or Crisis Response System?: A complexity science approach to organizational crises. Management Decision, 44(7), 892-907.

Park, M.-S., \& Kayatekin, S. A. (2000). McCloskey, economics as conversation, and Sprachethik. [Article]. Cambridge Journal of Economics, 24(5), 565.

Peach, T. (2002). Interpreting Ricardo: A further reply to Straffians. [Article]. Cambridge Journal of Economics, 26(3), 381-391. 
PottsA, N. (2005). The relevance of Marx to all students of economics, no matter the level. [Article]. International Journal of Social Economics, 32(9), 827-851.

Rhodes, C., \& Brown, A. D. (2005). Narrative, Organizations, and Research. International Journal of Management Reviews, 7(3), 167-188.

Shelton, K. (2008). Stories of Leaders and Followers. Leadership Excellence, pp. 2-2. Retrieved from http://search.ebscohost.com/login.aspx?direct=true \&db=buh\&AN=31821685\&site= ehost-live

Simmons, A. (2006). The story factor: Perseus Books Cambridge, MA, USA.

Söderbaum, P. (2000). Business Companies, Institutional Change, and Ecological Sustainability. [Article]. Journal of Economic Issues, 34(2), 435.

Strauss, A., \& Corbin, J. (1990). Basics of Qualitative Research: Grounded Theory Procedures and Techniques. Newbury Park, CA: Sage.

Thompson, C. J. (1997). Interpreting Consumers: A Hermeneutical Framework for Deriving Marketing Insights from the Texts of Consumers' Consumption Stories. Journal of Marketing Research, 34(4), 428-455.

Van Dijk, T. A. (1975). Action, Action Description, and Narrative. New Literary History, 6, 275294.

Van Manen, M. (1990). Researching Lived Experience. Ontario: State University of New York Press.

van Marrewijk, A. H. (2009). Corporate headquarters as physical embodiments of organisational change. [Article]. Journal of Organizational Change Management, 22(3), 290-306.

Wachtman, E., \& Johnson, S. L. (2009). The Persuasive Power of Story. (cover story). [Article]. Marketing Management, 18(1), 28-34.

Waistell, J. (2006). Metaphorical mediation of organizational change across space and time. [Article]. Journal of Organizational Change Management, 19(5), 640-6541.

Wycherley, I. (2005). Tales for Change: Using Storytelling to Develop People and Organisations/Stories Trainers Tell: 55 Ready-to-Use Stories to Make Training Stick/Death by Meeting: A Leadership Fable. [Book Review]. Personnel Review, 34(2), 262-267.

Yannopoulou, N., \& Elliott, R. (2008). Open versus closed advertising texts and interpretive communities. [Article]. International Journal of Advertising, 27(1), 9-36. 